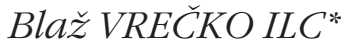

\title{
CLIMATE CRISIS: TIME TO RETHINK ECONOMIC PLANNING BY DEMYSTIFYING CAPITALISM AND ITS MARKET(S)
}

\begin{abstract}
The purpose of the article is to open up epistemological space for revitalising the idea of democratic economic planning as a viable alternative vision. It argues that a proper development of the idea must be preceded by a comprehensive critical interrogation of a hegemonic multidimensional ideological mystification of capitalism and its markets. By utilizing Marxist and eco-socialist insights the article identifies and analyses several central ideological mystifications that enact an epistemic closure. These range from the obfuscation of capitalism's role in creating the climate crisis as an inherently unsustainable system, to the mystification of its non-evolutionary origins, to the obfuscation of the role economic planning plays in contemporary capitalism, to the mystification of markets as ideal spaces of freedom and innovation obfuscating the ever present market-related oppression, exploitation and environmental devastation, and to silencing concrete historical examples of democratic economic planning such as project Cybersyn that should serve as an inspiration for imagining an alternative order.
\end{abstract}

Keywords: climate change, ideological mystification, democratic economic planning, capitalism, neoliberalism

\section{Introduction}

Although the present corona crisis has reduced global economic activity, harmful emissions, natural resource exploitation and various types of pollution, this should only be seen as a temporary slowdown of an otherwise unsustainable, ecologically devastating and exploitative economic system. The climate crisis caused by the capitalist global system is becoming more

* Blaž Vrečko Ilc, PhD, Assistant Professor, Faculty of Social Sciences, University of Ljubljana, Slovenia.

DOI: $10.51936 /$ tip. $58.2 .341-360$ 
and more critical. Most political and economic elites and the public regard the climate crisis as being in need of globally coordinated solutions. Still, this perception is not universally shared, with far-right populist elites and governments (e.g. Trump's USA) and their supporters rejecting any type of coordination as an attack on national sovereignty. They perceive climate change itself as a hoax and a left-wing conspiracy. Despite the appearance that these two positions are diametrically opposed and mutually exclusive, they both operate in a shared capitalist framework. More specifically, they operate in the contemporary neoliberal capitalist framework (see Mirowski, 2014). Climate change denialism and the dominant solutions proposed for the climate crisis share a common imaginary characterised by unlimited faith in capitalism. The climate change denialism camp reinforces the existing status quo by doubling down on existing neoliberal policies and practices that exacerbate inequality, poverty and ecological degradation. This is accompanied by nationalistic, racist and chauvinistic rhetoric and policies that strive to harness and refocus people's anger due to their deteriorating living conditions onto historically discriminated minorities. On the other hand, the hegemonic camp of supporters of global solutions is reinforcing the status quo by viewing climate change as the result of market failures and 342 primarily as an issue of wrong incentives. The solutions formulated in this framework are market and technologically based and elite/technocratically led. Despite it being declared that these solutions will establish a more sustainable system, the reality of these imagined and implemented solutions (e.g. emission markets) is their failure to address climate change (see Rogers, 2013). This failure of the dominant solutions is inextricably connected with the hegemony of the neoliberal capitalist ideology that allows no space for an alternative politico-economic order. Hence, the central issues of climate change related to environmental inequality and climate justice, the issue of people's needs vs. corporate profits, the issue of public goods and the commons vs. private property etc. cannot be addressed properly. When political, economic and scientific elites do consider these issues, they address them via an implicit market-driven, top-down, technocratic, status-quo-reproducing framework that gives the appearance of progressiveness while reproducing the status quo. Yet, most climate scientists argue that our societies should be radically transformed in view of the climate crisis (Wallace-Wells, 2020). It is understandable that their specific areas of expertise mean they do not offer ideas on how this can be achieved. However, even in the scientific fields that should offer and popularize alternative visions there seems to be a predominant silence concerning alternative frameworks for a radical transformation of society. This is disconcerting considering that the present status quo cannot be retained if we wish to respond to the climate crisis and mitigate its most serious consequences. But even if we mitigate these 
consequences, our societies will still need to adapt to the changed climate as we inevitably face up to the impacts of a warmer planet.

The idea of democratic economic planning is potentially one of the most suitable frameworks for imagining, formulating and implementing the radical transformation of existing politico-economic and societal arrangements to make them sustainable in an effort to address the climate crisis. If it is properly developed and implemented, the idea can offer both a vision for reducing the effects of the climate crisis and for adapting societies to the new situation. It removes the need and the logic for the continuous accumulation of profits and the continuous intensification of exploitation of natural resources and human labor (see Phillips \& Rozworski, 2019).

However, the idea of democratic economic planning needs to be revitalised before we can develop it further. The present context is characterized by a specific ideological mystification of capitalism and denigration of proper alternatives above all the notion of (democratic) economic planning. This enables the closure of the epistemological space and prevents the popularization of alternative visions of society among the general public, a necessary precondition for the needed radical socio-political and economic transformation (see Patel \& Moore, 2017).

Hence, the central question that will guide our analysis is how to open up epistemological space to revitalize the idea of democratic economic planning as a viable framework for a radical transformation of society? We argue that the proper development of the idea of democratic economic planning, must be preceded by the identification and interrogation of the specific ideological mystifications of the present capitalist system that enable an epistemic closure. By utilizing and building upon Marxist (e.g. Neurath, 2006; Wood, 2017; Phillips \& Rozworski, 2019) and Eco-socialist (e.g. Patel \& Moore, 2017; Saito, 2017) analyses, critiques and demystification of capitalism, its genesis, nature, characteristics and planetary consequences the article addresses several dimension of the contemporary mystification of capitalism to enact an opening of the epistemological space. These dimensions range from capitalism's connection to climate change, its genesis and nature, its central contemporary characteristics, and the capitalist critiques of democratic economic planning in its theoretical and concrete forms. Hence, in the first part the article addresses the most obvious epistemological obstacle namely the lack of understanding by the public concerning the severity of the climate crisis and its fundamental cause. It critically interrogates this lack of understanding as a crucial feature of the present ideological mystification of capitalism that is performed by the neoliberal ideology, which also provides the hegemonic framework for most "realistic" solutions for the climate crisis that reaffirm the unsustainable status quo. This is followed by a demystification of the historical genesis of capitalism 
as the mystification of its origins naturalises capitalism and represents the starting point of capitalist critiques of planning in contemporary elite and popular discourses, thereby establishing a central obstacle for opening up epistemological space. In the third part, we address the actual centrality of planning in contemporary capitalism, thereby demystifying its current functioning and problematizing the presumed impossibility of planning in an advanced economy. In part four, we analyse the socialist calculation debate and by utilizing the forgotten insights of Otto Neurath demystify the central arguments for capitalist markets and the critique of planning offered by von Mises and Hayek, the 'fathers' of neoliberalism, thereby addressing the obstacle of the presumed theoretical impossibility of democratic economic planning. Finally, we focus on Cybersyn, the Chilean project of socialist democratic planning implemented in the early 1970 s by the Allende government and crushed by the Pinochet coup, thereby addressing the obstacle of the presumed non-existence of historical precedence of democratic economic planning. We conclude the article by briefly reflecting on how our analysis opens up epistemological space for a future vision for democratic planning.

\section{The misunderstood severity, consequences and nature of the climate crisis as a product of capitalism and its ideology}

A proper understanding of the climate crisis is a crucial prerequisite in the process of imagining an alternative politico-economic system. Most people do not understand the serious consequences the climate crisis holds for societies. Various negative trends and process are intensifying, affecting almost every facet of the general functioning and survival of human societies. Although there is considerable uncertainty regarding the climate crisis' future intensity, it all depends on the extent of global warming. According to IPCC (Intergovernmental Panel on Climate Change) scientists, any global rise in temperature beyond 2 degrees by the year 2100 will bring catastrophic consequences (IPCC, 2015). In the context of the existing policies of major states and regional organisations, a 2- to 3-degree rise is a realistic scenario (Wallace-Wells, 2020). If we take this as our starting point, we may predict the intensification of extreme fires, extreme heat waves and long droughts. There will be shorter periods of cold temperatures, sea levels will rise, and floods will increase. Coastal settlements will become unliveable. There will also be shorter, yet extremely intense wet seasons. These changes will catastrophically affect the living conditions of a substantial part of the human population by lowering access to fresh water and reducing the capacity to produce food, while they will also destroy/limit any economic activity that depends on natural resources, including tourism. Hunger, epidemics 
and pandemics will reach unprecedented 1)evels of intensity and regularity (Steffen, Broadgate, Deutsch, Gaffney \& Ludwig, 2015). These processes will precipitate fundamental societal, political and economic destabilisation. Such destabilisation will range from socio-political and economic collapse in parts of the world that will bear the brunt of climate change. We will witness an exponential rise in migration from these parts to areas with a milder climate and a still-functioning society. This will then intensify all negative economic and socio-political trends in countries that are less directly affected. All conflicts over rare resources will intensify. Conflicts among states and especially among regional and global powers and superpowers will grow as these states strive to consolidate their primacy or attain it amidst general planetary climate chaos. Further intensification of all reactionary, racist, xenophobic and fascist movements, practices and public policies that will inevitably popularise these ideas among the public are to be expected (Wainwright \& Mann, 2018; Wallace-Wells, 2020).

A proper response to the seriousness of the crisis is lacking. Neither the claims made by most climate scientists that a radical transformation of our way of life is needed, nor the mobilisation of school children by climate media stars like Greta Thunberg seem able to change the situation. There is no substantial societal and political discussion underway concerning the alternative visions for our societies. This is due to the hegemony enjoyed by the neoliberal framework with respect to solving the climate crisis. This framework transforms the older techno-utopian frameworks for solving societal problems via the notions of free markets and competition that will lead to optimal solutions. The hegemony of neoliberalism may be seen in the notions of 'green capitalism', 'green growth' and sustainable development. They all propagate a mix of technocratic-technological-financial-market solutions for all central issues concerning the climate crisis. Various analyses of these 'solutions' demonstrate that they do not and will not radically alter the existing unsustainable politico-economic arrangements (Rogers, 2013). The dominant solutions for the climate crisis are an obstacle to successfully addressing the climate crisis.

These ideas form part of an operation conducted by economic elites and the professional-managerial class to co-opt the struggle against the climate crisis for the purpose of further accumulation and profits. Climate crisis is a direct outcome of the capitalist system. The genesis of global capitalism and the sharp rise of carbon emissions in the late $18^{\text {th }}$ century coincide. This expresses the causal link between capitalism and the devastation of environment, which is historically unprecedented. Although capitalism is a very recent social formation, no prior formation altered our relationships with each other and the environment in such fundamental ways. Capitalism relies on a permanent drive towards accumulation (Patel \& Moore, 2017). 
It is organised around commodity production and consumption, driven by the imperative of expanding the accumulation of surplus value by realising profits. Aggregate economic growth is the paramount objective of all capitalist nation-states as, without it, there are no profits. Capitalism needs to convert ever growing amounts of natural resources into means of production and commodities for sale and consumption. It must treat nature as a set of resources to be exploited (Wainwright \& Mann, 2018). The ecological crisis is a fundamental contradiction of capitalism because its drive to accumulation is eroding its own material conditions, which eventually confronts it with the limits of nature (severely deteriorated climate conditions) (Saito, 2017).

In the present neoliberal hegemony, alternative solutions that strive for a radical transformation such as democratic planning are dismissed for being unrealistic. Regardless of the many catastrophic consequences of capitalism, the explicit and implicit notion that capitalism is the most efficient, fair and natural system which offers the most choice is hegemonic (Fisher, 2009). This notion rests on a multidimensional mystification of capitalism, which centres specifically on the idealised notions of the free and competitive market(s) that colonise people's imaginations. Hence, to remove the

346 obstacle to imagining alternatives like democratic planning, this multidimensional mystification of capitalism must be thoroughly dismantled.

\section{Demystifying the genesis and foundational characteristics of capitalism}

The mystification of the genesis of capitalism is one of the biggest obstacles to imagining alterative visions like democratic economic planning as viable. The dominant narrative is based on a circular way of thinking that assumes the a priori existence of capitalism whose central characteristics such as profit-maximisation are always-already present in human societies. It appears when the shackles that constrain people's natural propensity to exchange on the market are enabled by the removal of political, ideological and religious obstacles and when a never clearly defined extent of commerce, urbanisation and wealth accumulation is achieved. The narrative posits that capitalism developed in Europe as it was the place where the supposed obstacles were finally lifted, and a certain natural development was reached. The imagining of capitalist markets as a simple mechanism of exchange plays the key part in this narrative since trade and markets have existed for millennia (Wood, 2017). The capitalist market appears by way of evolution and not revolution. This mystification holds a specific ideological function, namely to make capitalism appear like a universal natural progression of human societies and the pinnacle of human evolution. The 
transhistorical understanding of the market is underpinned by the notion that the market, regardless of its historical form, is a space of opportunity and choice. Market forces that ensure economic rationality are coercive only insofar as they force economic actors to maximise opportunities and choice. Capitalist society can thus be imagined as the most rational, freest and best society for creating opportunities and choice (Slobodian, 2018).

Considering the actual origin of capitalism, the hegemonic narrative is implausible. It establishes a teleology that directly supports the existing status quo by making capitalism appear as an expression of human nature or social and biological evolution. It has a major unacknowledged issue concerning the place and time of the origin of capitalism, which makes the commercial thesis, the thesis concerning the centrality of the urban economy and the notion that capitalism was the teleological pinnacle of social and technological evolution, very problematic. Capitalism first appeared in the English countryside in the late $16^{\text {th }}$ century (Marx, 2013). England was at that time far less commercially and technologically developed than the Dutch Republic, which was a vastly more logical birthplace of capitalism due to its extensive long-distance trade and its bourgeois dominated government. Capitalism originated in the countryside, not in the English towns and cities, which subverts the urban economy thesis. It did not evolutionarily develop from pre-capitalist market relations and is not the product of universal laws of development but of human decisions in a specific historical geopolitical and socio-political setting. It required a revolutionary transformation of human-human and human-nature relations. The radical transformation of social-property relations in the English countryside is key to understanding this revolution. When the market penetrated the production of food and social reproduction became mediated and determined by the market, capitalism was born (see Wood, 2017).

The origin of this complex process in England and specifically in the English countryside was predicated on a certain political and economic context. Compared to other European states, England was the most centralised state in the $16^{\text {th }}$ century when a clear division was established between the extra-economic sovereign power of the monarchy and the extensive economic power of the elites. This division and the elites' massive landholdings ushered in the development of a unique agricultural system. In this system, most of the land was rented by tenants. The truly revolutionary nature of this arrangement lay in the transformation of the rent as the rents charged by the elites started to depend on the commercial profits made by their tenants, who began to be dependent on the market. Access would be given to the land to those able to produce competitively and therefore pay higher rents. It is here that market opportunity was transformed into market dependence, oppression and an imperative. This stimulated commodification, 
increased productivity, and self-sustaining economic development. Small farmers were gradually dispossessed and became wage labourers for capitalist tenants (Marx, 2013). Hence, market dependence led to mass proletarianization.

This radical transformation was not solely the product of economic forces but was accomplished in unison with the judiciary and intellectuals (e.g. John Locke). Together, they established a novel understanding of property. Property also became inextricably linked with the notion of exclusivity and improvement, understood as increasing the land's productivity to gain profit. This conception was made central in legitimising not only the colonial dispossession of native lands but also the domestic dispossession of farmers. Only productive labour that realises a profit was established as the basis of property (see Lukšič, 2016). The term producer began to connote a person who actively uses property for investment. Economic principles took on a moral meaning and expropriation was considered as an act benefitting the common good (Wood, 2017). Despite the centrality of economic forces, the nation-state was quintessential for consolidating the novel property system and instrumental in establishing favourable conditions for capitalist accumulation not only in England but later all around the world (Parenti, 2020).

This novel societal formation proved to be extremely productive, bringing two main consequences. First, it meant an exceptionally large population could be sustained. Second, due to its productivity, it required a relatively small part of the population to be engaged in agriculture, which resulted in greater numbers of people without property. This mass was then transformed into wage laborers and consumers of cheap goods, which led to the establishment of an unprecedented national competitive domestic market and formed the foundations of the English industrial revolution. The English domestic market was qualitatively specific as it was centred on cheap consumer goods while also being uniquely limited by the restricted powers of consumption of its main consumers: wage laborers. This created general pressure to produce cheaply and efficiently and to focus on economies of scale by constantly improving the productivity of labour by introducing novel technologies. The British industrial revolution universalised the capitalist mode of production that started in the countryside. It also began to radically influence economic development on the Continent and globally. It gradually universalised the imperatives of capitalism, especially the competitive pressures and capital accumulation while making people's basic needs and environmental protection secondary to profits, thereby gradually destroying the conditions for its own existence (Saito, 2017; Wood, 2017). Since the advent of industrial capitalism, "economies inserted in the international trading system and depending on it for their material needs, 
whatever the prevailing social property relations (sic!), would be subject to capitalist imperatives" (Wood, 2017: 145). The character of this transformation and its speed depended on the geopolitical context of each society and state (e.g. a colonial metropole or a colony). While European powers were coerced to adapt so as to be competitive with the UK, the European colonies were transformed into spaces as providers of cheap natural resources, cheap labour power and as overall dependent economies whose productive capacities were complementary and not in competition to those of the metropole (Patel \& Moore, 2017). It is telling that the global expansion of capitalism resulted in environmental destruction wherever capitalism expanded without being accompanied by the rising living standards that characterised the later phases of industrialisation in Britain, Europe and its (former) settler colonies (e.g. USA, Canada).

To reiterate, capitalism is not an evolutionary end state of human development and an expression of human nature. Hence, a radical politico-economic transformation of contemporary societies is not contrary to evolution and the iron laws of human development.

\section{The neoliberal mystification of the market, the denigration of economic planning, and the silent legacy of the socialist calculation debate}

The rethinking of democratic economic planning is also obstructed by mystification of the capitalist market. This is one of the core elements of capitalist ideologies that secure capitalist hegemony in each historical context. The coordinates of the contemporary mystification of the market primarily derive from the neoliberal ideology, which over the last 40 years has come to dominate the existing capitalist hegemony (Mirowski, 2014). The modern neoliberal notion of the capitalist market is the silent legacy of the socialist calculation debate, which originates in Otto Neurath's paper on a socialised economy presented in 1919 to the Bavarian Workers' and Soldiers' Council during the short-lived Munich Soviet Republic (Phillips \& Rozworski, 2019). Neurath argued in the paper that a novel kind of planned economy should be established, one that would focus on satisfying basic human needs and not on profitability. This prompted a response from (neo)liberal thinkers that sought to undermine the idea of the socialist planned economy. The debate was never a technical debate concerning the market's efficiency and the impossibility of planning but a "conflict about political order, economic history, and the possibility of perpetual peace" (Whyte, 2020: 33). The central issue was whether humans have a choice in submitting themselves to the market and whether an inclusive, emancipatory and deliberate process of collective self-determination is possible and desirable. It is in this context 
that the contemporary commonsensical notion that there is no rational alternative to the capitalist market was born. This notion was initially elaborated during a debate involving the neoliberals Ludwig von Mises and Friedrich Hayek, whose mystification of the market and critique of planning is the core part of today's hegemonic neoliberal ideology. Their mystification of the market is multidimensional, although it serves the simple goal of establishing the market as unassailable. From the technical perspective, the presumed superiority of the market price is the starting point. The price is deemed to determine every economic relationship. Von Mises claimed that markets are primary mechanisms for aggregating and calculating information in a specific economy, while market prices are the aggregates of all information concerning production and consumption (Von Mises, 2008). Hayek went even further by claiming that markets also create knowledge that would not exist without markets. Only the invisible coordination of the market can link the information isolated in the heads of individual economic actors (Hayek, 1945). The market with its "godly" capacity to create knowledge and support innovation will inevitably produce solutions to all issues.

From the political dimension, Von Mises defended the market as the only possible avenue for mutually beneficial, voluntary relations. Markets supposedly foster peace and tolerance as they allow individuals to pursue their own plans. They are necessary for political freedom. But the market itself is imagined as a form of impersonal domination to which everyone must submit for the benefit of an efficient economy. Von Mises imagined the market required international peace for uninterrupted functioning. He acknowledged that capitalism spread not only by commerce but also violent imposition, which he deemed necessary for the development of civilisation (Von Mises, 2008). Neoliberals legitimised violence for imposing capitalist markets globally and internally when the capitalist order was threatened by upheavals. In defending the markets, neoliberals imagined the state as playing a central role. The state's explicit function was to secure the legitimacy of the system (of property relations) while simultaneously preventing the masses via democratic politics from regulating the markets (Slobodian, 2018).

The neoliberals attacked planning as a collectivist interventionist action as inefficient, wasteful and impossible, and a threat to individual freedom, a road to a totalitarian order, a civilisational regression to a barbaric state, and a recipe for the destruction of peaceful coexistence (Whyte, 2020: 38). Humans do not have a choice concerning submitting themselves to the market. Hence, neoliberals rejected the notion that an inclusive, emancipatory and deliberate process of collective self-determination was possible and desirable (Hočevar, 2018). 
What is forgotten is that Neurath's critique of market capitalism fundamentally obliterates every central neoliberal argument and that he articulated his ideas in the context of an experiment with an alternative politicoeconomic order. He argued that capitalism is systemically irrational since its imperative is profit, not human needs, and that the fundamental question about the central purpose of the economy cannot be reduced to an economic accounting issue. Neurath rejected the notion that the capitalist market is the final evolutionary stage of universal progress. By illustrating the ills brought by capitalism whose imperatives necessitate its global expansion and subjugation of non-market relations to the market, he demonstrated the fundamentally destructive, oppressive and unfree nature of capitalism. He argued that capitalism will always lead to war, colonisation and civilising missions due to the general profit motive. He claimed that the capitalist market is a site of oppression and discipline and called for democratic planning as the primary principle regulating the economy. He believed there are no purely technical decisions concerning what to produce or build. Every such decision is ultimately political and cannot be decided by a calculation (Neurath, 2006). To add to Neurath's argument, in capitalism every investment and every produced good is rationalised based on profit and not from the point of view of a good's use value, ecological sustainability, and positive social impact. Hence, capitalists invest in useless, unsustainable and socially harmful goods and services if they are profitable and vice versa. The imperative of profit also always leads to a crisis of overproduction. Neurath claimed that planning could provide a space for democratic decision-making. For him, the main issue in economic planning at the outset was the way it changes the control over economic life. If workers' power remains limited, we cannot then talk about proper socialist planning and we end up with a soviet command economy (Neurath, 2006).

Neurath's vision has been forgotten even among the socialist left because planning itself became an anathema in contemporary common sense (Whyte, 2020). Today's hegemonic understanding of the economy is predicated on abhorrence of economic planning and the presupposed dualism and incompatibility of planning and markets. Yet this dualism is an obfuscation of the reality of the omnipresence of planning in capitalism, as we address in the next chapter.

\section{Planning in capitalist corporations as subversion of the mystification of market capitalism}

The text-book illusion of the market is a space populated by economic agents with similar market power and information derived from the market price that have a similar range of choices among which they choose on the 
grounds of their rational decisions based on risk calculations. In this illusion, no space is left for mezzo or macro level planning because all planning takes place on the level of the individual economic actor. The reality of our everyday experience in the present neoliberal capitalist arrangements paints a substantially different picture. Despite the symbolic and material centrality of markets in and for capitalism, its contemporary form is characterised by the ubiquity of planning. Although the latter is present almost everywhere, multiple agents of the neoliberal order work tirelessly to obfuscate and silence this fact for two chief reasons. First, despite its constant failures, "negative externalities" and coercive nature, the idealised market must be preserved as the ideological centre of the commonsensical imaginary of our present system since it symbolises freedom, choice and opportunity, thereby legitimising the whole capitalist system as the best possible arrangement that is/can be. Second, the existing forms of planning in the capitalist system pose the problem of illustrating the actual nature of the oppressiveness and coercion of capitalism. These forms of planning are authoritarian, hierarchical and undemocratic.

In neoliberal globalised capitalism, planning is carried out in multiple ways but hidden behind the façade of market relations. Although market relations among economic actors are central to a capitalist society, these relations represent the minority of relations that form the everyday experience of individuals. Most of us spend large parts of our working time in relatively structured, hierarchical authoritarian, non-market relations that characterise modern private and public organisations. Even contemporary markets must be initially planned, established and preserved. State institutions continuously intervene in various markets to stabilise and consolidate them (Jones, 2020). The market(s) connects only businesses with businesses and businesses with consumers. Market relations do not regulate the internal organisation and functioning of a capitalist firm or other organisational forms of the capitalist system. Most mainstream understandings of capitalism do not focus on the actual internal functioning of firms. The latter exposes the inconvenient fact of the market economy that relies heavily on planning. More precisely, it relies on authoritarian planning which concentrates power in the hands of capitalists and upper management, while simultaneously disciplining workers (Phillips \& Rozworski, 2019). This fact destroys any simple argument about the inevitability of the market price mechanism because it presupposes that market relations are a superior form of resource allocation and regulation of the supply and demand of commodities. Firms do not rely on internal markets to achieve efficiency, but rely on planning. They (strategies and bosses) plan the redistribution of resources among certain departments, they plan what each individual worker must do, which tasks must be accomplished, and how and where they should be 
accomplished. Individual workers do not have any choice and freedom in this regard. Planning in contemporary capitalism in relations with workers is utilised to discipline people to perform specific tasks without having their own input and to suppress their interests (Phillips \& Rozworski, 2019). Even beyond large firms, planning is omnipresent in the form of business plans, risk management, and financial projections. Planning is very apparent in the details of capitalist economic activity. Accounting and management systems, strategic management and risk management, logistics and information systems require and depend on planning (Jones, 2020).

But it could easily be claimed that planning in capitalism is only possible at the level of each individual corporation, not at the macro societal level. However, today's biggest corporations like Walmart and Amazon function not only internally but as planned economies in relation to their vast number of suppliers. These corporations utilise planning to make their operations more efficient, predictable and stable, thereby ensuring a high level of profits and/or a dominant market position. Walmart and Amazon have integrated their suppliers and other actors in their ecosystem into a highly planned arrangement (Phillips \& Rozworski, 2019). Walmart as the largest privately-owned company is in many respects a planned economy. Its individual departments, stores and, most importantly, its suppliers do not compete with each other. It was one of the first companies to establish mechanisms to address the bullwhip effect in supply chains that is caused by fluctuations in consumer demand that can potentially create vast inefficiencies due to ever growing over- or under-stocking down the supply chain. The bullwhip effect can only be prevented in a situation where consumption (and orders) is equal to supply in all temporal intervals. The greater the planning, trust, transparency of information, cooperation, and openness there is in a supply chain, the more it resembles the ideal situation. Efficiency in a specific supply chain is not a product of competition but of planning. Walmart's satellite-based information infrastructure enables realtime planning not according to an initial stable plan concerning consumption. It enables a direct link between the planning carried out by Walmart in cooperation with its supplier and real-time information concerning the sale of all the commodities in its stores, thereby substantially improving information and reducing unpredictability throughout the supply chain (Phillips \& Rozworski, 2019: 30-39).

Along with Walmart, Amazon directly subverts the common thesis that economic planning is only possible for infrastructure and similar segments and not for consumer goods. Similarly to Walmart, Amazon has integrated its suppliers into a planned system. It has developed a sophisticated planned economy that is based upon the enormous amount of data. It knows more about its customers than any other retailer. It is able to plan consumption 
based on the past activities of its individual customers. It plans consumption via algorithms that operate based on extremely accurate and segmented data. As the biggest online retailer, it has successfully faced the biggest logistical challenges ever encountered by a capitalist company. The challenge is how to deliver the right item in the shortest amount of time, most efficiently, to millions of customers every day. Amazon is faced with an unprecedented optimisation problem (e.g. how to deliver - routes, availability of the means of transport, weather conditions). Concerning planning, this poses an extreme mathematical problem regarding the enormous number of variables that even with today's computational capabilities would be unsolvable. The revolutionary nature of Amazon's approach lies in its simplification of issues. Amazon's planning does not perfectly solve the optimisation problem. Its solution is the best possible approximation that is still substantially better than leaving its solution up to the market. Amazon understands planning as a mechanism that works regardless of its simplifications (Phillips \& Rozworski, 2019: 76-99).

Given the substantial extent of planning in the mega corporations of contemporary capitalism, we must not only stress its efficient nature but above all its primary goals. The inherent capitalist logic of the existing planning is

354 inextricably connected with the ever-growing exploitation of workers and natural resources and thus the ever-growing inequality, authoritarianism, and ecological devastation. Planning in capitalism is efficient but relies on the brutal coordinates of the system and its imperatives. This naturally raises the question of whether the organisational and technological capabilities developed by a capitalist mega corporation could be appropriated and coopted to transform the present unsustainable system into an egalitarian, sustainable politico-economic and societal order. Learning from capitalist corporations should simultaneously be accompanied by studying the potential of forgotten historical examples of democratic socialist economic planning.

\section{The Cybersyn project and the Chilean cybernetic socialist experiment as the forgotten precedence of democratic socialist economic planning}

The spectre of Soviet planning always hovers above any discussion of economic planning. It is generally presented as the ultimate proof that planning only leads to totalitarianism, inefficiency, economic crisis and ecological devastation, thereby colonising our understanding of planning (Jones, 2020). This colonization serves a specific political goal of delegitimising macro-economic planning as the potential alternative way of imagining socio-political arrangements. Additionally, it silences historical examples of democratic socialist economic planning from which we could draw our 
inspiration for a future order. For instance, the short-lived Chilean project Cybersyn (Projecto Synco) represents the biggest experiment ever conducted in macro-economic planning based on the principles of democratic socialism. Despite this, it is practically unknown in mainstream social sciences (Medina, 2011).

Cybersyn was developed in collaboration between Allendes Chilean socialists and the British cybernetic theoretician Stafford Beer. It lasted until the coup d'état by Pinochet on 9/11 1973. The project was one of the most ambitious experiments to develop a system for democratic socialist planning of the economy. Chilean socialists sought to establish a society that would radically differ from western capitalism and the authoritarian planning system of the Soviet Union. They identified the Englishman Stafford Beer as an expert able to help them fulfil their vision. Beer was a cybernetic theoretician who primarily focused on developing systems that would be decentralised but would retain specific, limited centralised strategic control. His goal was to ensure the system's stability without compromising the autonomy of its constitutive parts. This was analogous to the Chilean government's goal since it wished to expand macro-economic state planning without endangering the people's liberties and democratic political institutions. It wanted to establish a broadly participative, decentralised and antibureaucratic form of economic management (Medina, 2011).

The general architecture of Cybersyn was based on Beer's cybernetic notion of continuous feedback loops in the form of the continuous aggregation of data from local producers (factories) at a central nodal point (a brain) - the project's operations room. The key decision-making people of this operations room were key members of the government headed by the prime minister. The design of Cybersyn ensured there would never be an overload of data that would flow to the operations room and that decisions would therefore be possible. The data received would be automatically evaluated and there would be an intervention in the production and distribution process only when a substantial deviation would appear in supply and demand. This enabled flexible coordination that was able to solve extremely complex logistical problems. Beer claimed a system for economic planning could never be non-adaptive and fixed by a predetermined model (Medina, 2011). Flexible coordination preserved the autonomy and democratic self-organisation of factories that was crucial for implementing the principles of democratic socialism. Despite integration that enabled limited yet crucial vertical control to stabilise the system and make strategic decisions, each level of the system remained irreducible, recursive and scalable. This complex system could synchronise itself without the actions of omnipotent managers. In addition, the human element was central to the system because its goal was not automation but a close symbiosis between 
technology and the people working on the Cybersyn project (Gardiner, 2020: 6). To deal with the threat of the concentration of power and authority by a technocracy, Beer even imagined a complementary but never implemented Cyberfolk project intended to gather ordinary people's feedback on government policies and actions in relation to their needs in real time via an analogue, completely anonymised system of remote controls attached to the television set of all Chilean families (Medina, 2011).

Cybersyn proved its potential during a time of crises when internal and external reactionary forces organised a strike of truck owners, thus threatening the functioning of the whole Chilean economy. By utilising Cybersyn, the government was able to maintain economic activity even with substantially reduced capacities to transport materials and goods. The project also proved that cybernetic systems can be established with limited cutting-edge technology since the project utilised an existing computer (only 1 cuttingedge computer work station) and communication technology (telex stations) to establish a novel, unprecedented system that was able to foster a radical, economic, political and societal transformation from capitalism to democratic socialism (Medina, 2011).

However, the project could not prevent the government's downfall organised by combined reactionary forces. In the internal and external subversion of Chilean socialism, Cybersyn itself was misrepresented in the Western media as a totalitarian system of centralised economic planning (Medina, 2011). Despite this negative propaganda and the general politicoeconomic crisis that seriously hampered its full development, Cybersyn also had specific internal issues. Worker participation was severely lacking and was not an integral part of the system's design. The relations of production did not change as managers and engineers consolidated their class power over workers in the nationalised factories. Gender inequality was also never addressed and the project reaffirmed unequal gender roles via its design, decision-making and organisation of work whereby women could only be implicitly imagined as supporting the work of men (Medina, 2011). Hence, even progressive policies and projects can strongly limit general emancipation if they do not directly address asymmetrical power relations between workers and the managerial-professional classes and genders while also limiting their mobilisation potential and emotional identification.

These issues may be attributed to the project's initial improper design. Yet we must also consider the possibility that these issues reflect the limitations of cybernetic thinking. The cybernetic principles of Cybersyn were those of British cybernetics, which emphasised non-representationalism, decentralisation and spontaneity that seem emancipatory and progressive. However, they may also be interpreted as being an expression of a new structure of power and control established in the context of contemporary 
technocapitalism that to some degree also functions on the basis of fluidity and openness and the free participation of individuals who make presumably free choices ${ }^{1}$ and self-organise into communities (Gardiner, 2020). This relevant critique does not delegitimise Cybersyn as an inspiration for developing and implementing novel socialist planning systems since it fails to acknowledge that technology can be designed and used in a socialist way. It does not acknowledge the role of the state in this process and the role the general political sphere can play as the context in which the ideological struggle is most openly fought and where the general coordinates of the design and use of technologies are established, consolidated and transformed.

\section{Conclusion}

In face of the ever more dire consequences of the climate crisis a radical transformation of the present hegemonic neoliberal capitalist order is not only crucial for solving the most central issues precipitating the climate crisis but also for reducing its already inevitable effects on our societies. We proposed that it is time to rethink and develop the notion of democratic economic planning in this search for an alternative order. However, we argued that we firstly need to revitalize the notion of democratic economic planning. We claimed that that could only be achieved by opening up epistemological space whose closure is precipitated by a multidimensional ideological mystification of capitalism and its markets and the denigration of proper alternatives above all democratic economic planning.

Hence, the article sought to identify and critically interrogate the various central dimensions of the ideological mystification of the present capitalist system and denigration of democratic economic planning as a relevant strategy for opening up epistemological space and revitalizing and popularizing democratic economic planning as a vision of an alternative sustainable order. In this context, we firstly critically interrogated the most pronounced obstacle for imagining an alternative order namely the lack of understanding among the general public considering the severity and nature of the climate crisis and its relation to capitalism. The analysis demonstrated that this misunderstanding is the product of the mystification of capitalism performed by the hegemonic neoliberal ideology that obfuscates the central role of capitalism in the climate crisis and promotes solutions that are fundamentally unsustainable.

Secondly, we analysed the mystification of the origins of capitalism that represents a less pronounced but fundamental obstacle for imagining

1 This freedom is circumscribed as the major corporations of technocapitalism rely on their market effects that radically reduce choice (Larson, 2020). 
alternatives. The interrogation demonstrated that capitalism was not a product of social or biological evolution of humans or human nature but a contingent result of a specific structural context and human agency. Thirdly, by revisiting the socialist calculation debate, we demystified the now hegemonic neoliberal understandings of the market as a space of freedom, rationality and innovation that represents another central dimension of contemporary mystification of capitalism. Our analysis demonstrates the irrationality, oppressive nature, unsustainability and unspontaneous nature of the market while also problematising neoliberals' critique of planning as theoretically impossible and leading to authoritarianism and violence by demonstrating the theoretical possibility and the democratic potential of planning. Fourthly, we further demystified the capitalist market by interrogating the actual functioning of capitalism at the level of corporations. We demonstrated that contrary to ideological denigration of economic planning, planning is omnipresent in contemporary capitalism and that in many ways the largest global corporations resemble planned economies. But because planning is utilised for capitalist ends it is environmentally destructive, undemocratic, oppressive and concentrates power in the hands of management. In the final part, we interrogated another central dimension of the contemporary mystification of capitalism and an obstacle for imagining alternatives namely the presumed lack of historical examples of democratic economic planning by examining project Cybersyn. The latter was a Chilean democratic socialist experiment for macro-managing the whole economy via cybernetic networks that although short-lived due to Pinochet's coup d'état proved successful during a national crisis. Its visionary nature should be along with our other central insights considered a crucial element in the central undertaking of our analysis namely a comprehensive critical interrogation of the multidimensional ideological mystifications of the present neoliberal capitalist order. As we argued this demystification is a necessary first step in opening up epistemological space that would enable us to collectively imagine, popularize and further develop the notion of democratic economic planning as a viable alternative order and to not succumb to the alures of capitalist realism. A further theoretical and practical development of the framework of democratic economic planning must be considered a crucial part of present and future political struggles. To politically mobilize societies for the needed transformations, we must have a clear vision of how democratic economic planning could function at the macro level of societies, nationally, regionally and globally. 


\section{BIBLIOGRAPHY}

Fisher, Mark (2009): Capitalist realism: Is there no alternative? Ropley: Zero Books. Gardiner, Michael. E. (2020): Automatic for the People? Cybernetics and Left Accelerationism. Constellations.

Hayek, Friedrich (1945): The use of knowledge in society. The American economic review 35 (4): 519-530.

Hočevar, Marko (2018): Hayekova teorija demokracije: trg proti ljudstvu. In Družba in družbena gibanja 50 let po 1968, 101-105. Ljubljana Slovensko sociološko društvo.

Jones, Campbell (2020): Introduction: The Return of Economic Planning. South Atlantic Quarterly 119 (1): 1-10.

Larson, Rob (2020): Bit tyrants : the political economy of Silicon Valley. Chicago: Haymarket Books.

Lukšič, Igor (2016): Aktualnost in akutnost Lockove koncepcije lastnine. Teorija in praksa 53 (3): 625-644.

Marx, Karl (2013): Capital : Volume One. Ware: Wordsworth Editions Ltd.

Medina, Eden (2011): Cybernetic revolutionaries: Technology and politics in Allende's Chile. Cambridge: MIT Press.

Mirowski, Philip (2014): Never let a serious crisis go to waste : how neoliberalism survived the financial meltdown. London: Verso.

Neurath, Otto (2006): Economic Writings: Selections 1904-1945 (Vol. 23). Berlin: Springer Science \& Business Media.

Parenti, Christian (2020): Radical Hamilton : economic lessons from a misunderstood founder. London: Verso.

Patel, Raj, \& Jason W. Moore (2017): A history of the world in seven cheap things: A guide to capitalism, nature, and the future of the planet. Berkely: University of California Press.

Phillips, Leigh, \& Michal Rozworski (2019): The people's republic of Walmart : how the world's biggest corporations are laying the foundation for socialism. London: Verso.

Rogers, Heather (2013): Green gone wrong : dispatches from the front lines of ecocapitalism. London: Verso.

Saito, Kohei (2017): Karl Marxs Ecosocialism Capital, Nature, and the Unfinished Critique of Political Economy. New York: Monthly Review Press.

Slobodian, Quinn (2018): Globalists : the end of empire and the birth of neoliberalism. Cambridge: Harvard University Press.

Steffen, Will, Wendy Broadgate, Lisa Deutsch, Owen Gaffney \& Cornelia Ludwig (2015): The trajectory of the Anthropocene: the great acceleration. The Anthropocene Review 2 (1): 81-98.

Von Mises, Ludwig (2008): Economic calculation in the socialist commonwealth. Auburn: Ludwig Von Mises Institute.

Wainwright, Joel, \& Geoff Mann (2018): Climate Leviathan: A political theory of our planetary future. London: Verso Books.

Wallace-Wells, David (2020): The Uninhabitable Earth. New York: Tim Duggan Books. 
Whyte, Jessica (2020): Calculation and Conflict. South Atlantic Quarterly 119 (1): 31-51.

Wood, Ellen Meiksins (2017): The origin of capitalism: a longer view. London: Verso.

\section{SOURCES}

IPCC (2015): Climate Change 2014 synthesis report - Summary for Policymakers (9789291691432 9291691437). Accessible at http://www.ipcc.ch/report/ar5/ syr/, 24. 5. 2021. 